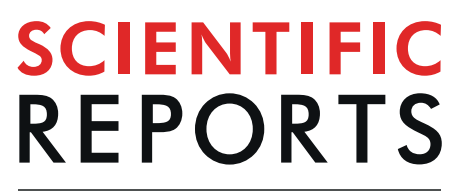

natureresearch

\title{
OPEN Wood volatiles as attractants of the confused flour beetle, Tribolium confusum (Coleoptera: Tenebrionidae)
}

Received: 16 November 2018

Accepted: 30 July 2019

Published online: 08 August 2019

\begin{abstract}
Masatoshi Hori ${ }^{1}$, Yoshimi Aoki ${ }^{1}$, Kazutaka Shinoda ${ }^{2,3}$, Mitsuo Chiba $^{2}$ \& Rikiya Sasaki ${ }^{2}$
Confused flour beetles are serious pests of stored grain products, and therefore, it is important to efficiently monitor and control their populations. Aggregation pheromones are commercially used for monitoring this beetle but their efficacy has been questioned and they may be inadequate for practical use. Food attractants as well as pheromones are commonly used for monitoring stored-product insects. However, food attractants may not be effective in the case of food handling facilities, which are already filled with food odours. The ancestors of flour beetles may have been associated with dead or decomposing woody vegetation, so we investigated the attractiveness of several wood odours to beetles using a pitfall olfactometer. The beetles were strongly attracted to all wood odours tested: Castanea crenata, Magnolia obovata, Paulownia tomentosa, Prunus jamasakura, and Zelkova serrata. The attractiveness of these wood odours was also stronger than that of the odours of the usual food of these beetles. Supercritical $\mathrm{CO}_{2}$ extracts of these species of wood were also attractive to the beetles. The $Z$. serrata extract was the most attractive among these extracts, and was further analysed by gas chromatography mass spectrometry. One major compound, (-)-mellein, was detected in the extract. Synthetic $( \pm)$-mellein attracted the beetles.
\end{abstract}

The large-scale use of insecticides for controlling stored-product insects is not desirable in food processing or storage facilities because of the risk of contaminating food products. Therefore, it is important to monitor these pests so that effective management strategies can be employed to maintain good levels of hygiene based on data pertaining to the pests collected through effective monitoring traps. Although repellents have been studied for several stored-product insects such as Lasioderma serricorne (Fabricius) ${ }^{1-3}$, Callosobruchus chinensis (L.) ${ }^{4}$, Tribolium confusum Jacquelin du Val, and Sitophilus zeamais Motschulsky ${ }^{5}$, their effective application methods in food facilities are limited.

The confused flour beetle, T. confusum (Coleoptera: Tenebrionidae) is a worldwide serious insect pest of stored grains and their products, similar to the well-known red flour beetle, T. castaneum (Herbst). Aggregation pheromones are commonly used as an attractant in the monitoring traps of the flour beetles in food facilities ${ }^{6-11}$. However, it has been found that the attractiveness of the aggregation pheromones currently used is limited ${ }^{12,13}$, reducing their efficacy. Therefore, it is important to develop more effective alternative attractants for these beetles. Food attractants are also commonly used in the monitoring traps for stored insect pests ${ }^{14-16}$, and there are many reports on the attractiveness of host-food odours to insects ${ }^{17-24}$. In the flour beetles also, food volatiles have been well studied as attractants for traps $s^{6,20,21,25}$; however, their efficacy is limited in food facilities ${ }^{26}$ owing to the high occurrence of food odours already present.

The stored-product pests of the family Tenebrionidae belong, with few exceptions, to the subfamily Ulominae $^{27}$. Most members of this subfamily live under bark or in rotting wood as semipredators and scavengers $^{27}$. The various species of Tribolium, which belong to the Ulominae, are also to be found under bark ${ }^{28}$. It is considered that Tribolium have originally occurred primarily in rotting logs and under tree bark feeding on plant and animal detritus, and on insect eggs and pupae ${ }^{29,30}$. Therefore, it is reasonable to assume that T. confusum and

${ }^{1}$ Graduate School of Agricultural Science, Tohoku University, Sendai, Miyagi, 980-8572, Japan. ${ }^{2}$ Insect Pheromone \& Traps Division, Fuji Flavor Co., Ltd., Hamura, Tokyo, 205-8503, Japan. ${ }^{3}$ Present address: Pest Control Engineering Department, Seibu Kasei Co., Ltd., Shimonoseki, Yamaguchi, 750-0067, Japan. Correspondence and requests for materials should be addressed to M.H. (email: hori@tohoku.ac.jp) 
T. castaneum may be attracted to odours from these woody habitats. If these odours are effective at attracting these beetles, then they should also be effective in food facilities as wood odours significantly differ from food odours. In this study, we investigated the attractiveness of several wood odours to T. confusum and found them to be effective attractants. Our findings suggest that odours of the original habitats or foods of stored-product pests are the promising resources for screening attractants for them.

\section{Materials and Methods}

Insects. Adults of the confused flour beetle, Tribolium confusum Jacquelin du Val, maintained in our laboratory were used for the tests. They were reared on wheat flour ('Yukichikara'; Sugawara Seifun Seimen Kojo, Iwate, Japan) containing $5 \%$ dry brewer's yeast (Ebios ${ }^{\circledR}$; Asahi Food \& Healthcare Co., Tokyo, Japan), and maintained at $25 \pm 1{ }^{\circ} \mathrm{C}$ and ca. $70 \%$ relative humidity under a $16 \mathrm{~L}: 8 \mathrm{D}$ photoperiod.

Stored food products. We investigated the attractiveness of the odours of five stored food products that are suitable food for T. confusum: wheat flour ('Yukichikara'; Sugawara Seifun Seimen Kojo, Iwate, Japan), polished rice ('Sasanishiki', milling of rice grains to 90-92\% of weight), unpolished rice ('Hitomebore'), corn flour (Nippon Flour Mills Co., Tokyo, Japan), and soybean flour (Matsuda Seifun Co., Miyagi, Japan). The polished rice and unpolished rice were pulverised using a mill (Sibata Personal Mill, SCM-40A, Sibata Scientific Technology Ltd., Saitama, Japan) in preparation for the tests.

Wood. We used five species of wood, Castanea crenata, Magnolia obovata, Paulownia tomentosa, Prunus jamasakura, and Zelkova serrata, for the tests. All species of timber (1-2 m long) used for the tests were purchased from Kanayama-Chip-Center Co., Ltd., Gifu, Japan. The diameters of the purchased timber were ca. 400, $450,150,200$, and $150 \mathrm{~mm}$ for C. crenata, M. obovata, P. tomentosa, P. jamasakura, and Z. serrata, respectively. Each piece of timber was naturally seasoned in the laboratory of Fuji Flavor Co., Ltd. (Kanagawa, Japan) at room temperature $\left(24 \pm 3^{\circ} \mathrm{C}\right)$ for about three months after purchase. For attractiveness of wood odours, each piece of timber was divided into wooden blocks (ca. $50 \mathrm{~mm}$ long) using an electric saw. Wooden blocks were crushed into chips using a crusher (Wonder Blender ${ }^{\circledR}$, WB-1; Osaka Chemical Co., Ltd., Osaka, Japan). Chips were naturally dried in the laboratory of Tohoku University (Sendai, Japan) at room temperature $\left(24 \pm 3^{\circ} \mathrm{C}\right)$ for more than two weeks. Once dry, the chips were pulverised using the mill and were used for the bioassay.

Supercritical carbon dioxide $\left(\mathrm{CO}_{2}\right)$ extraction of wood. All species of wood were chipped using an electric wood planer (M192, Makita Co., Aichi, Japan). Chips of each type of wood were crushed using a hammer crusher (NH-34, Sansho Industry Co., LTD., Osaka, Japan) and sifted using a 0.4-mm meshed sieve. The powder of each species of wood was extracted using supercritical $\mathrm{CO}_{2}$ using extraction apparatus from a plant of Fuji Flavor Co., Ltd. (Tokyo, Japan). Crude extracts were separated into lipid-soluble and water-soluble phases. The volatility and dispersibility of attractants are important in practical use. Lipid-soluble phases usually have more abundant volatile components than water-soluble phases. Therefore, in this study, the water-soluble phases were discarded, and only the lipid-soluble phases were used as extracts. Extraction pressure, extraction temperature, solvent ratio, separation pressure, and separation temperature were $25 \mathrm{MPa}, 15^{\circ} \mathrm{C}, 20: 1,4 \mathrm{MPa}$, and $20^{\circ} \mathrm{C}$, respectively. The extracts containing solids were centrifuged at $8000 \mathrm{~g}$ for $10 \mathrm{~min}$ to remove them. The weight of the wood used for the extractions and the weight of each extract obtained were as follows: C. crenata (wood powder: $27.62 \mathrm{~kg}$; extract: $30 \mathrm{~g})$, M. obovata $(17.92 \mathrm{~kg} ; 140 \mathrm{~g})$, P. tomentosa $(30.42 \mathrm{~kg} ; 280 \mathrm{~g})$, P. jamasakura $(29.14 \mathrm{~kg} ; 50 \mathrm{~g})$, and Z. serrata $(28.47 \mathrm{~kg} ; 20 \mathrm{~g})$.

Chemical analysis of supercritical $\mathrm{CO}_{2}$ extract of $Z$. serrata. The supercritical $\mathrm{CO}_{2}$ extracts of Z. serrata were analysed by GC-MS (Shimadzu GCMS-QP2010 Ultra, equipped with a DB-5MS column, $30 \mathrm{~m} \times 0.25 \mathrm{~mm}$ i.d., $0.25 \mu \mathrm{m}$ film thickness, J\&W, Santa Clara, CA, USA). The extract was diluted to $5 \%$ (w/w) in hexane and filtered through a Minisart ${ }^{\circledR} \mathrm{RC} 15$ filter $(0.45 \mu \mathrm{m}$ pore size; Sartorius Stedim Biotech, Göttingen, Germany). The filtrate $(1 \mu \mathrm{l})$ was injected into the GC/MS. Helium was used as the carrier gas at a column head pressure of $100 \mathrm{kPa}$. The GC was set for split injection (split ratio, 100:1). The temperature program of the column oven was as follows: initial temperature $60^{\circ} \mathrm{C}, 3^{\circ} \mathrm{C} / \mathrm{min}$ to $195^{\circ} \mathrm{C}$. The injector, detector, and interface temperatures were $220^{\circ} \mathrm{C}, 200^{\circ} \mathrm{C}$, and $240^{\circ} \mathrm{C}$, respectively. Mass spectral data were analysed using Shimadzu GCMS Solution with the Wiley Registry ( $9^{\text {th }} \mathrm{ed}$.), National Institute of Standards and Technology (NIST05), and Flavor and Fragrance Natural and Synthetic Compounds (FFNSC ver. 1.3) mass spectral databases. Major compounds of the extract were identified by comparing GC retention times and mass spectra with those of the authentic $( \pm)$-mellein synthesised in Fuji Flavor Co., Ltd. The concentration of mellein in the Z. serrata extract was calculated from the calibration curve for the authentic mellein.

In order to identify the enantiomer of mellein in the Z. serrata extract, (-)-mellein was purchased from Funakoshi Co., Ltd (Tokyo, Japan). Mellein in the extract, $( \pm)$-mellein and (-)-mellein were analysed by GC-MS (Shimadzu GCMS-QP2010 Ultra, equipped with an InterCap CHIRAMIX column, $30 \mathrm{~m} \times 0.25 \mathrm{~mm}$ i.d., $0.25 \mu \mathrm{m}$ film thickness, GL Sciences Inc., Tokyo, Japan). Helium was used as the carrier gas at a column head pressure of $100 \mathrm{kPa}$. The GC was set for split injection (split ratio 100:1). The temperature program of the column oven was as follows: isotherm for $180 \mathrm{~min}$ at $130^{\circ} \mathrm{C}, 10^{\circ} \mathrm{C} / \mathrm{min}$ increase to $150^{\circ} \mathrm{C}$, and isotherm for $20 \mathrm{~min}$ at $150^{\circ} \mathrm{C}$. The injector, detector, and interface temperatures were $230^{\circ} \mathrm{C}, 250^{\circ} \mathrm{C}$, and $180^{\circ} \mathrm{C}$, respectively. Retention time of the peak of mellein in the extract was compared with those of $( \pm)$-mellein and $(-)$-mellein.

Bioassay. Behavioural responses of T. confusum to the wood odours were investigated with the pitfall-trap olfactometer (Supplementary Fig. 1). The olfactometer comprised a glass Petri dish ( $246 \mathrm{~mm}$ dia.) with four round holes $(30 \mathrm{~mm})$ with four plastic containers $(60 \times 60 \times 100 \mathrm{~mm})$ set under the holes. The containers acted as traps for the beetles. Two out of the four containers were used as treatment traps and the others were used as control 


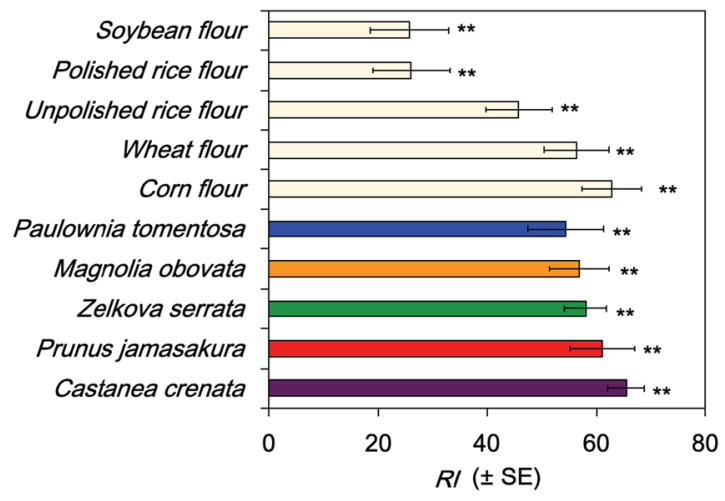

Figure 1. Attractiveness of the wood and food odours to Tribolium confusum in pitfall-trap olfactometer tests. Test wood or food material ( $2 \mathrm{~g}$ ) was placed in each of two treatment traps; the two control traps were empty. Fifty adult beetles starved for $24 \mathrm{~h}$ were tested for each replication. The total number of beetles in the two treatment traps was compared with the two control traps $3 \mathrm{~h}$ after the start of the assay. $R I=100 \times(n t-n c) / t o t$, where $n t, n c$, and tot represent the total number of beetles in the treatment and control traps, and the total number of beetles released in the olfactometer, respectively. $* *$ indicates significant differences between the treatment and control traps (Wilcoxon matched-pairs signed-ranks test: $P<0.01, n=10$ ).

traps. The treatment traps and the control traps were arranged alternately in all the experiments. Each hole was covered with a piece of polyethylene mesh (opening of mesh: $5 \mathrm{~mm}$ ). A sheet of filter paper with four round holes $(30 \mathrm{~mm})$ was stuck on the Petri dish so that the holes overlapped with those of the Petri dish. The beetles walking on the filter paper were attracted to the odours and fell into the traps through the meshes of the holes. Fifty beetles of 3- to 4-week-old unsexed adults that were starved for $24 \mathrm{~h}$ were released on to the centre of the filter paper. All bioassays were conducted at $25 \pm 1{ }^{\circ} \mathrm{C}$ and approximately $70 \%$ relative humidity under dark conditions to remove any potential influence of light on behavioural responses. The total number of beetles in the two treatment traps was compared with the two control traps $3 \mathrm{~h}$ after the start of the assay. In the preliminary tests, approximately equal number of beetles were trapped in each of the four traps when all traps were empty. Each comparison was replicated 10 times; except for the assays using mellein, in which eight replications were conducted for each dose. The glass Petri dish and the traps of the olfactometer were washed with soapy water (LIQUINOX ${ }^{\circledR}$; Alconox, Inc., White Plains, NY, USA), and the sheet of filter paper and the pieces of mesh were replaced after every replication. The positions of the treatment and control traps were alternated after half of the replications had been completed.

The total number of beetles in the traps of the treatment and control groups were analysed using a Wilcoxon matched-pairs signed-ranks test. The attractiveness of each sample to the beetles was estimated by a response index according to the formula:

$$
R I=100 \times(n t-n c) / t o t
$$

where $n t, n c$, and tot represent the total number of beetles in the treatment and control traps, and the total number of beetles released in the olfactometer, respectively.

In the tests of attractiveness of wood odours, test wood or food material $(2 \mathrm{~g})$ was placed in each of two treatment traps; the two control traps were empty. In the tests of attractiveness of extracts and mellein, a disk ( $12 \mathrm{~mm}$ dia., $3 \mathrm{~mm}$ thickness, material: polyethylene/ethylene-vinyl acetate copolymerisation fibre) impregnated with $100 \mu \mathrm{l}$ of the acetone solution of each sample (doses of extract: $0.1,1$, or $10 \mathrm{mg} /$ disk; doses of mellein: $0.05,0.1$, 1 , and $10 \mathrm{mg} /$ disk) was placed in each treatment trap, whereas a disk impregnated with only $100 \mu \mathrm{l}$ acetone was placed in each control trap. Both treatment and control disks were allowed to dry to remove the acetone before they were placed in the traps. In the choice test between the Z. serrata extract and wheat flour odour, wheat flour $(2 \mathrm{~g})$ was placed in each control trap and the control disk impregnated with only $100 \mu \mathrm{l}$ of acetone was placed on the wheat flour, whereas only the treatment disk impregnated with $100 \mu \mathrm{l}$ of the acetone solution of $Z$. serrata extract (extract dose: $1 \mathrm{mg} /$ disk) was placed in each treatment trap. In attractiveness of mellein, $( \pm)$-mellein synthesised by Fuji Flavor Co., Ltd. was used because of the cost. The cost of either asymmetrically synthesising or purchasing $(-)$-mellein was too high for use in the bioassay.

\section{Results}

Attractiveness of wood odours. We investigated the attractiveness of odours from five species of wood: Castanea crenata, Magnolia obovata, Paulownia tomentosa, Prunus jamasakura, and Zelkova serrata, to T. confusum, using a pitfall-trap olfactometer. In addition, the attractiveness of these odours was compared to that of odours of suitable foods for the beetles, i.e. polished rice, unpolished rice, wheat flour, corn flour, and soybean flour. All five wood odours were similarly attractive to the beetles showing response index (RI) values of ca. 55-65, which were similar levels to those of unpolished rice, wheat, and corn flours, and were considerably higher than those of soybean and polished rice flours (Fig. 1). The odour of C. crenata showed the highest RI value, i.e. 65.4. This value was similar to that of the corn flour odour (RI value: 62.8), which showed the highest attractiveness among food odours. 


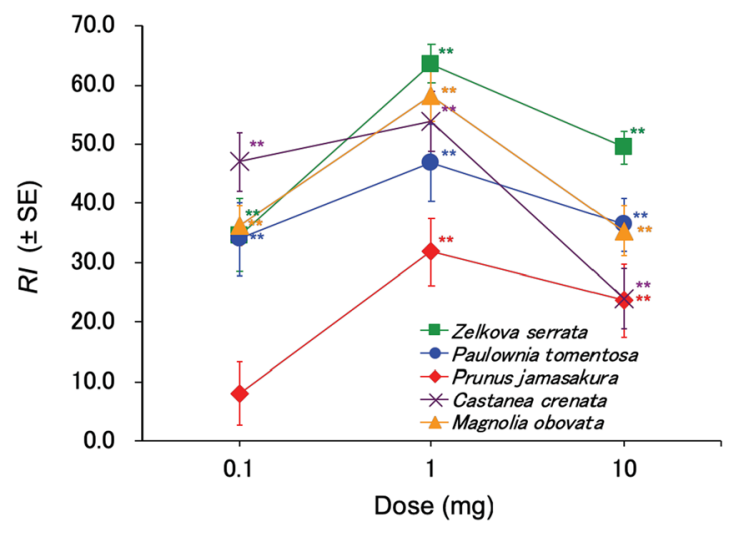

Figure 2. Attractiveness of the supercritical $\mathrm{CO}_{2}$ extracts of woods to Tribolium confusum in pitfall-trap olfactometer tests. A disk impregnated with $100 \mu \mathrm{l}$ of acetone solution of each sample was placed in each of the two treatment traps, whereas a disk impregnated with only $100 \mu \mathrm{l}$ acetone was placed in each of the two control traps ( 50 adult beetles starved for $24 \mathrm{~h}$ per replication). The total number of beetles in the two treatment traps was compared with the two control traps $3 \mathrm{~h}$ after the start of the assay. $R I=100 \times(n t-n c) /$ tot, where $n t, n c$, and tot represent the total number of beetles in the treatment and control traps, and the total number of beetles released in the olfactometer, respectively. $* *$ indicates significant differences between the treatment and control traps (Wilcoxon matched-pairs signed-ranks test: $P<0.01, n=10$ ).

Attractiveness of wood extracts. In the tests for attractiveness of wood odours, the odours of all five species of wood tested were highly attractive to T. confusum; therefore, we investigated the attractiveness of supercritical carbon dioxide $\left(\mathrm{CO}_{2}\right)$ extracts of these five species of wood using the pitfall-trap olfactometer. All extracts tested showed the highest attractiveness at a dose of $1 \mathrm{mg}$ among the doses tested. The extract of $Z$. serrata exhibited the highest activity with a RI value of 63.6 at a dose of $1 \mathrm{mg}$ (Fig. 2). The attractiveness of the extract of P. jamasakura, of which the wood odour showed the highest level of activity next to that of C. crenata (Fig. 1), was the lowest performing among the extracts tested. The extract of $C$. crenata showed the highest attractiveness among the extracts tested at a dose of $0.1 \mathrm{mg}$ and relatively high attractiveness at a dose of $1 \mathrm{mg}$, whereas it showed the lowest attractiveness, similar to that of P. jamasakura at a dose of $10 \mathrm{mg}$.

Choice test between the $Z$. serrata extract and wheat flour odour. In the tests for attractiveness of wood extracts, the $Z$. serrata extract showed the highest attractiveness at doses of 1 and $10 \mathrm{mg}$ among the extracts tested. Hence, we allowed T. confusum to choose between the Z. serrata extract ( $1 \mathrm{mg})$ and wheat flour $(2 \mathrm{~g})$ odours using the pitfall-trap olfactometer. The beetles chose the $Z$. serrata extract showing a RI value of 35.2 significantly more often $(P<0.01$, Wilcoxon matched-pairs signed-ranks test, $n=10)$.

Isolation and identification of semiochemicals from $Z$. serrata extract. We analysed the volatile compounds with low polarity contained in the $Z$. serrata extract by coupled gas chromatography/mass spectrometry (GC/MS). In the total ion chromatogram of the Z. serrata extract, one major peak was detected at the retention time of $30.2 \mathrm{~min}$ (Fig. 3a). This compound was identified as 3,4-dihydro-8-hydroxy-3-methyl-1H2-benzopyran-1-one (mellein) by comparing the gas chromatograph retention time and the mass spectra with those of a known sample of mellein (Fig. 3b,c). It was quantitatively analysed by comparing the peak area of total ion chromatogram of mellein contained in the Z. serrata extract with that of a known sample of mellein, which showed that the mellein concentration in the extract was approximately $0.5 \%$.

To identify the enantiomer of mellein in the Z. serrata extract, we compared the chiral GC/MS peak of mellein in the extract to those of $( \pm)$-mellein and $(-)$-mellein. Mellein in the extract and $(-)$-mellein showed one peak at a retention time of $191.0 \mathrm{~min}$, whereas $( \pm)$-mellein showed two peaks at retention times of $190.3 \mathrm{~min}$ and $191.0 \mathrm{~min}$. Therefore, the mellein in the extract was identified as the $(-)$ enantiomer.

Attractiveness of mellein. ( $( \pm)$-Mellein significantly attracted T. confusum at doses of $0.1-10 \mathrm{mg}$ showing a dose-response relationship (Fig. 4). RI values were ca. 40, 50, and 50 at doses of $0.1,1$, and $10 \mathrm{mg}$, respectively. Although the $Z$. serrata extract significantly attracted the beetles at a dose of $0.1 \mathrm{mg}$, which contains $0.0005 \mathrm{mg}$ of mellein (Fig. 3), $0.05 \mathrm{mg}$ of mellein was not attractive to the beetles (Fig. 4).

\section{Discussion}

The woods tested in this study belong to five different families representing four diverse orders of plants: $C$. crenata, M. obovata, P. tomentosa, P. jamasakura, and Z. serrata belong to Fagaceae (Fagales), Magnoliaceae (Magnoliales), Paulowniaceae (Lamiales), Rosaceae (Rosales), and Ulmaceae (Rosales), respectively. However, all wood odours were attractive to T. confusum and were similar in attractiveness to the odours of suitable foods for the beetles. Therefore, the beetles were attracted to wood odours from a variety of families and orders, which are not necessarily closely related. It is probable that T. confusum would be attracted to wide range of wood odours. It is considered that Tribolium originally fed on plant and animal detritus, and on insect eggs and pupae in rotting logs and under tree bark ${ }^{29,30}$. The positive chemotaxis of T. confusum to odours from various species of wood 
(a)
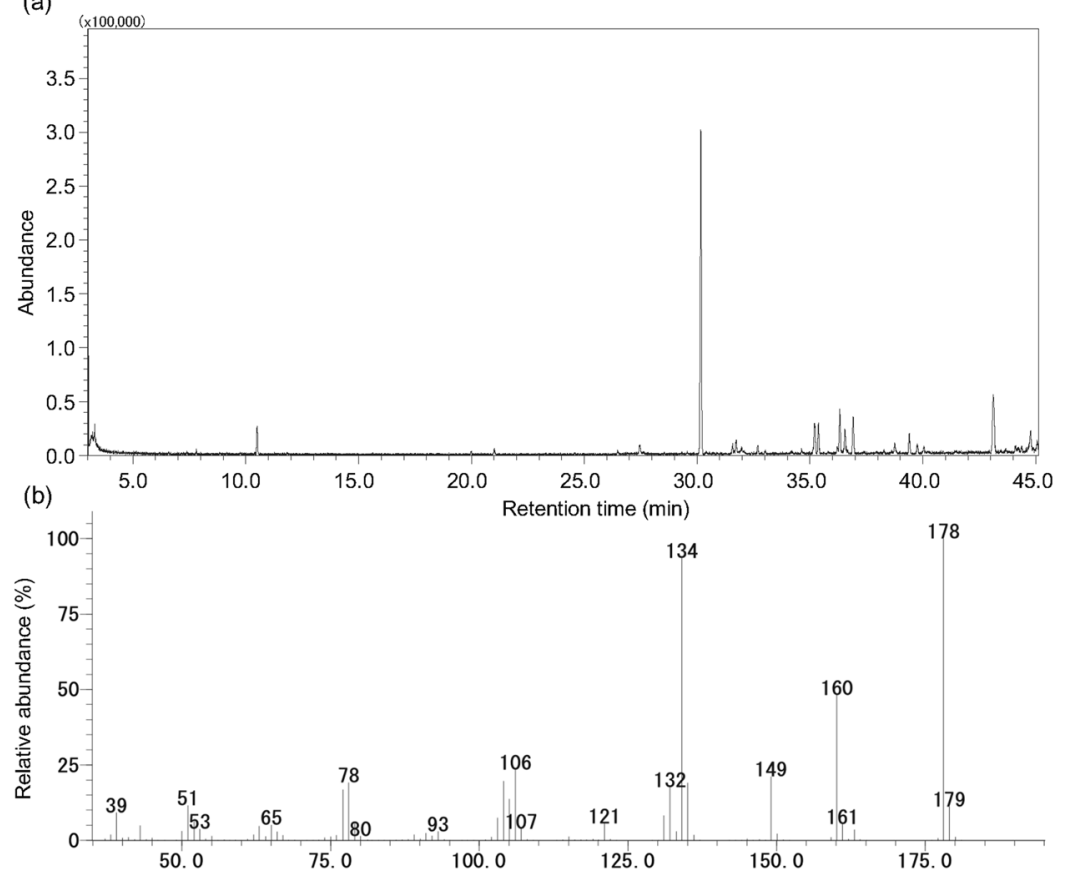

(c)

$\mathrm{m} / \mathrm{z}$

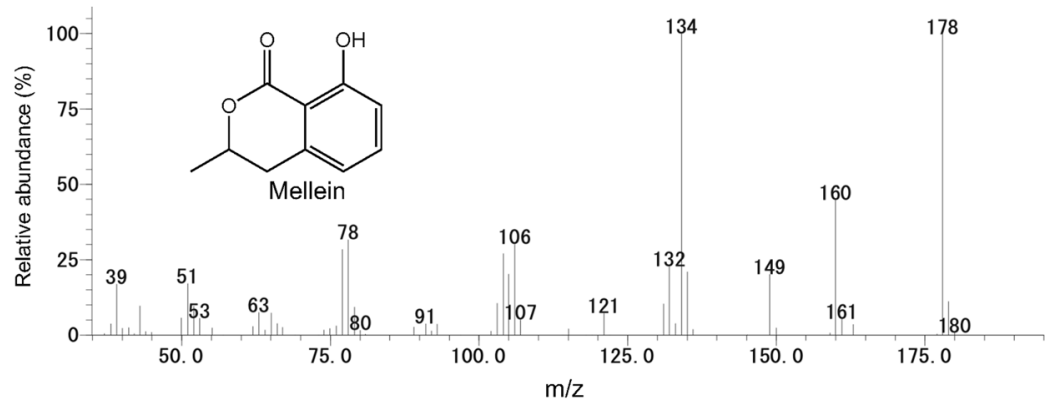

Figure 3. Gas chromatography/mass spectrometry analysis of supercritical $\mathrm{CO}_{2}$ extracts of Zelkova serrata. (a) Total ion chromatogram of the $Z$. serrata extract. (b) Mass spectrum of the peak detected at $30.2 \mathrm{~min}$. (c) Mass spectrum of the authentic sample of 3,4-dihydro-8-hydroxy-3-methyl-1H-2-benzopyran-1-one (mellein).

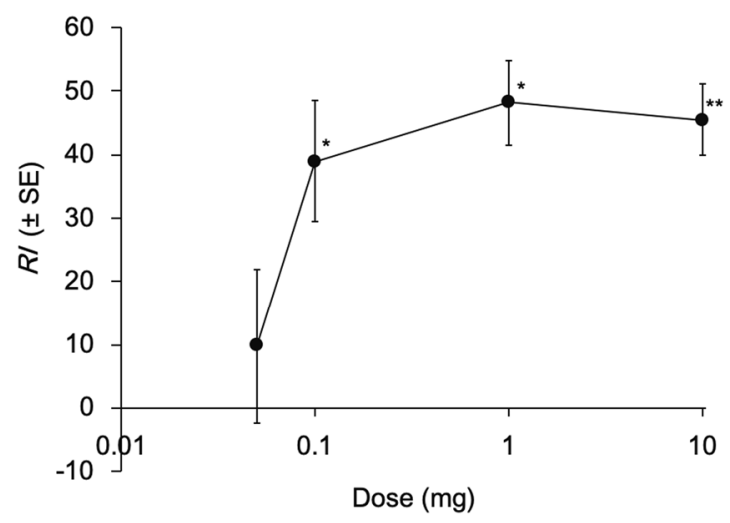

Figure 4. Attractiveness of $( \pm)$-mellein to Tribolium confusum in the pitfall-trap olfactometer tests. A disk impregnated with $100 \mu \mathrm{l}$ of acetone solution of $( \pm)$-mellein was placed in each of the two treatment traps, whereas a disk impregnated with only $100 \mu \mathrm{l}$ acetone was placed in each of the two control traps (50 beetles starved for $24 \mathrm{~h}$ per replication). The total number of beetles in the two treatment traps was compared with the two control traps $3 \mathrm{~h}$ after the start of the assay. $R I=100 \times(n t-n c) / t o t$, where $n t, n c$, and tot represent the total number of beetles in the treatment and control traps, and the total number of beetles released in the olfactometer, respectively. $* *$ indicates significant differences between the treatment and control traps (Wilcoxon matched-pairs signed-ranks test: $P<0.01, n=8$ ). 
observed in the present study may be related to the original habitat of this beetle. It is believed that food storage by ancient people began over 10,000 years ago ${ }^{31}$, offering a more stable habitat for insects, more sheltered from environmental changes and with a more abundant, steady supply of food. Certain species of Tribolium adapted to this environment ${ }^{32}$, losing their close association with rotting logs and bark leading to species with no association with these habitats, such as T. confusum ${ }^{33}$. The response of these beetles to woody odours observed in the present study suggests that olfactory recognition of the odours of their original habitat is likely to have been maintained genetically.

In this study, we investigated the olfactory responses of the beetles to odours of naturally seasoned timber using a pitfall-trap olfactometer. Therefore, the role of these findings in understanding chemotaxis in the natural environment is still unclear. In some Dendroctonus beetles (bark beetles), it is believed that pioneers can locate their coniferous hosts by attraction to volatiles and followers can quickly locate the hosts by using pheromones ${ }^{34}$. Further research with field trapping using aggregation pheromone and the volatiles of intact and decomposing trees and barks would help to clarify the specific chemotaxis in Tribolium beetles related to innate sexual, gregarious, or host-seeking behaviours.

Males of T. confusum produce an aggregation pheromone ${ }^{35,36}$; however, a previous study using the same pitfall-trap olfactometer as the present study found that the odour of conspecific males or females at high density (50 conspecifics/trap), without food odour, repelled both sexes, and that the odour at low density (5 or 10 conspecifics/trap) neither repelled nor attracted them ${ }^{37}$. Additionally, a high density of conspecifics did not suppress the attractiveness of wheat-flour odour to the beetles ${ }^{37}$. Therefore, we considered that the olfactory responses of the beetles to food-related volatiles observed in the present study were not affected by conspecific odours. For baited traps to be effective, it is required that the odour of the beetles initially trapped does not negatively affect the attractiveness of the trap to others. This study suggests that this is not the case for the attractiveness of wood odours.

Aggregation pheromones are commonly used in traps to monitor population of T. confusum, as well as $T$. castaneum in food handling facilities ${ }^{6-11}$ to aid in decisions to control them, but their efficacy has been questioned $^{12,13}$. Attractants screened from the volatile compounds of the beetle's food have also commonly been used for traps ${ }^{17-20,23}$. The efficacy of this method is, however, questionable, as food facilities are already filled with food odours, so it is difficult for the insects to recognise food attractants, being a useful pheromone synergist, volatilised from the traps ${ }^{26}$. If the odours from the original foods or habitats of the beetles differ from those of the stored foods, then the insects may easily discriminate between them. In the choice test between the $Z$. serrata extract and wheat flour odour, T. confusum significantly chose the Z. serrata extract compared with the wheat flour odour. Therefore, it is likely that volatile compounds from materials from the original habitat of stored-product insects can be useful as attractants.

It has been reported that mellein and its analogues have been isolated from trees ${ }^{38}$ and fungus in their bark ${ }^{39-41}$. Therefore, it is thought that the mellein identified in this study is from the Z. serrata trees itself and/or the fungus in the trees. In the current study, mellein was also detected as a minor compound in the M. obovata extract. Therefore, mellein may be one of the odours that attract $T$. confusum to the bark of trees. It is well known that mellein is produced by Aspergillus fungi, such as A. ochraceus and A. flavus ${ }^{42-44}$, which are common in soil, stored grains, and rotting wood ${ }^{39,45-49}$. The attraction of mellein might have played a role in the connection between original and current habitats.

The attractiveness of mellein was lower than that of the Z. serrata extract. In addition, the mellein concentration contained in the extract was approximately $0.5 \%$. In attractants used for traps, high diffusivity is required for the trap to be effective over long distances. We analysed all wood extracts by GC-MS after being dissolved in hexane and filtered to determine the volatility of their components, in order to identify highly volatile components with low polarity contained in the extracts. The results suggest that other attractants or synergists of mellein that are low-volatile components of high polarity, are likely to be contained in the $Z$. serrata extract. It is possible that some other attractants or synergists in addition to mellein occur in the lipid aqueous fractions not studied here.

In the current study, we used $( \pm)$-mellein in the bioassay although only the $(-)$ enantiomer was contained in the $Z$. serrata extract. It has been reported that some insect species can discriminate between enantiomers of certain volatile compounds ${ }^{50-55}$. It is thought that the lower activity of $( \pm)$-mellein compared to that of the Z. serrata extract may be due to interference with the attraction by the $(+)$ enantiomer which is not contained in the extract. Further study is needed on the differences in activity between each enantiomer and T. confusum.

To the best of our knowledge, this is the first study to show that the odours from the habitats or foods of stored-product insects, prior to their adaptation to human foods, may be useful as attractants in the traps used to monitor them. Beside T. confusum, many species of stored-product insects may be attracted to the odours of their original habitats or foods. This study provides novel ideas on the resources for screening attractants for stored-product insects.

\section{Conclusions}

T. confusum were attracted to wood-based odours, which are believed to correspond with their original habitats or foods, even more than to their usual food. This suggests that these wood-based odours would be ideal for use in monitoring traps and should be considered for future efforts to control stored-product pests.

\section{Data Availability}

The datasets are available from the corresponding author on reasonable request. 


\section{References}

1. Hori, M. Repellency of essential oils against the cigarette beetle, Lasioderma serricorne (Fabricius) (Coleoptera: Anobiidae). Appl. Entomol. Zool. 38, 467-473, https://doi.org/10.1303/aez.2003.467 (2003).

2. Hori, M. Repellency of hinokitiol against the cigarette beetle, Lasioderma serricorne (Fabricius) (Coleoptera: Anobiidae). Appl. Entomol. Zool. 39, 521-526, https://doi.org/10.1303/aez.2004.521 (2004).

3. Hori, M. Repellency of shiso oil components against the cigarette beetle, Lasioderma serricorne (Fabricius) (Coleoptera: Anobiidae). Appl. Entomol. Zool. 39, 357-362, https://doi.org/10.1303/aez.2003.467 (2003).

4. Shimizu, C. \& Hori, M. Repellency and toxicity of troponoid compounds against the adzuki bean beetle, Callosobruchus chinensis (L.) (Coleoptera: Bruchidae). J. Stored Prod. Res. 45, 49-53, https://doi.org/10.1016/j.jspr.2008.08.001 (2009).

5. Hori, M., Shimizu, C. \& Takano, K. Repellency of thujaplicins against three coleopteran stored-product insects, Tribolium confusum Jacquelin du Val (Tenebrionidae), Sitophilus zeamais Motschulsky (Curculionidae) and Lasioderma serricorne (Fabricius) (Anobiidae). House and Household Insect Pests 31, 77-83 (2009).

6. Barak, A. V. \& Burkholder, W. E. A versatile and effective trap for detecting and monitoring stored-product coleoptera. Agric. Ecosyst. Environ. 12, 207-218, https://doi.org/10.1016/0167-8809(85)90112-4(1985).

7. Trematerra, P. Integrated pest management of stored-product insects: practical utilization of pheromones. Anz. Schädlingskd. Pflanzenschutz Umweltschutz. 70, 41-44, https://doi.org/10.1007/BF01996919 (1997).

8. Phillips, T. W. Semiochemicals of stored-product insects: research and applications. J. Stored Prod. Res. 33, 17-30, https://doi. org/10.1016/S0022-474X(96)00039-2 (1997).

9. Cox, P. D. Potential for using semiochemicals to protect stored products from insect infestation. J. Stored Prod. Res. 40, 1-25, https:// doi.org/10.1016/S0022-474X(02)00078-4 (2004).

10. Neethirajan, S., Karunakaran, C., Jayas, D. S. \& White, N. D. G. Detection techniques for stored-product insects in grain. Food Control 18, 157-162, https://doi.org/10.1016/j.foodcont.2005.09.008 (2007).

11. Athanassiou, C. G., Kavallieratos, N. G. \& Campbell, J. F. Capture of Tribolium castaneum and Tribolium confusum (Coleoptera: Tenebrionidae) in floor traps: the effect of previous captures. J. Econ. Entomol. 109, 461-466, https://doi.org/10.1093/jee/tov307 (2016).

12. Shinoda, K. \& Habara, M. Trapping efficiency of pheromone trap for Tribolium. Pestology (Pest Control Research) 4, 56-57 (1989).

13. Duehl, A. J., Cohnstaedt, L. W., Arbogast, R. T. \& Teal, P. E. A. Evaluating light attraction to increase trap efficiency for Tribolium castaneum (Coleoptera: Tenebrionidae). J. Econ. Entomol. 104, 1430-1435, https://doi.org/10.1603/EC10458 (2011).

14. Chambers, J. Overview on stored product insect pheromones and food attractants. J. Kansas Entomol. Soc. 63, 490-499, https:// www.jstor.org/stable/25085215 (1990).

15. Burkholder, W. E. Biomonitoring for stored-product insects. In Management of insect pests with semiochemicals (ed. Mitchell, E. R.) 29-40, https://doi.org/10.1007/978-1-4613-3216-9_4 (Springer, 1981).

16. Toews, M. D. \& Nansen, C. Trapping and interpreting captures of stored grain insects. In Stored product protection (eds Hagstrum, D. W., Phillips, T. W. \& Cuperus, G.) 243-261 (Kansas State Research and Extension, 2012).

17. Pinniger, D. B. Food-bated traps; past, present and future. J. Kansas Entomol. Soc. 63, 533-538, https://www.jstor.org/stable/25085219 (1990).

18. Dowdy, A. K., Howard, R. W., Seitz, L. M. \& McGaughey, W. H. Response of Rhyzopertha dominica (Coleoptera: Bostrichidae) to its aggregation pheromone and wheat volatiles. Environ. Entomol. 22, 965-970, https://doi.org/10.1093/ee/22.5.965 (1993).

19. Obeng-Ofori, D. Behavioural responses of three stored product Coleoptera species to extract of carob (Locust bean), Ceratonia siliqua. Entomol. Exp. Appl. 68, 9-13, https://doi.org/10.1111/j.1570-7458.1993.tb01683.x (1993).

20. Phillips, T. W., Jiang, X.-L., Burkholder, W. E., Phillips, J. K. \& Tran, H. Q. Behavioral responses to food volatiles by two species of stored-product Coleoptera, Sitophilus oryzae (Curculionidae) and Tribolium castaneum (Tenebrionidae). J. Chem. Ecol. 19, https:// doi.org/10.1007/BF00985004 (1993).

21. Trematerra, P., Sciarreta, A. \& Tamasi, E. Behavioural responses of Oryzaephilius surinamensis, Tribolium castaneum and Tribolium confusum to naturally and artificially damaged durum wheat kernels. Entomol. Exp. Appl. 94, 195-200, https://doi. org/10.1046/j.1570-7458.2000.00619.x (2003).

22. Hori, M. Olfactory responses of Ephestia elutella (Lepidoptera: Pyralidae) to stored food odors. House and Household Insect Pests 28, 63-68 (2006).

23. Germinara, G. S., Cristofaro, A. D. \& Rotund, G. Behavioral responses of adult Sitophilus granarius to individual cereal volatiles. J. Chem. Ecol. 34, 523-529, https://doi.org/10.1007/s10886-008-9454-y (2008).

24. Hori, M., Miwa, M. \& Iizawa, H. Host suitability of various stored food products for the cigarette beetle, Lasioderma serricorne (Coleoptera: Anobiidae). Appl. Entomol. Zool. 46, 463-469, https://doi.org/10.1007/s13355-011-0062-x (2011).

25. Subramanyam, B. H., Wright, V. F. \& Fleming, E. E. Laboratory evaluation of food baits for their relative ability to retain three species of stored-product beetles (Coleoptera). J. Agric. Entomol. 9, 117-127, http://scentsoc.org/Volumes/JAE/v9/2/00092117.pdf (1992).

26. Campbell, J. F. Attraction of walking Tribolium castaneum adults to traps. J. Stored Prod. Res. 51, 17-30, https://doi.org/10.1016/j. jspr.2012.06.002 (2012).

27. Linsley, G. Natural Sources, habitats, and reservoirs of insects associated with stored food products. Hilgardia 16, 187-224, https:// doi.org/10.3733/hilg.v16n04p185 (1944).

28. Good, N. E. The flour beetles of the genus Tribolium. USDA Tech. Bull. 498, 1-58, http://ageconsearch.umn.edu/record/164672/files/ tb498.pdf (1936).

29. Sokoloff, A. The biology of Tribolium with special emphasis on genetic aspects. Vol. 2. (Clarendon Press, 1974).

30. Campbell, J. F. \& Runnion, C. Patch exploitation by female red flour beetles, Tribolium castaneum. J. Insect Sci. 3, 20, https://doi. org/10.1093/jis/3.1.21 (2003).

31. Kuijt, I. \& Finlayson, B. Evidence for food storage and predomestication granaries 11,000 years ago in the Jordan valley. PNAS 106, 10966-10970, https://doi.org/10.1073/pnas.0812764106 (2009).

32. Angelini, D. R. \& Jockusch, E. L. Relationships among pest flour beetles of the genus Tribolium (Tenebrionidae) inferred from multiple molecular markers. Mol. Phylogenet. Evol. 46, 127-141, https://doi.org/10.1016/j.ympev.2007.08.017 (2008).

33. Good, N. E. Biology of the flour beetles, Tribolium confusum Duv. and T. ferrugineum Fab. J. Agric. Res. 46, 327-334 (1933).

34. Pureswaran, D. S. \& Borden, J. Primary attraction and kairomonal host discrimination in three species of Dendroctonus (Coleoptera: Scolytidae). Agric. For. Entomol. 7, 219-230, https://doi.org/10.1111/j.1461-9555.2005.00264.x (2005).

35. Suzuki, T. \& Sugawara, R. Isolation of an aggregation pheromone from the flour beetles, Tribolium castaneum and T. confusum (Coleoptera: Tenebrionidae). Appl. Entomol. Zool. 14, 228-230, https://doi.org/10.1303/aez.14.228 (1979).

36. Suzuki, T. 4,8-Dimethyldecanal: the aggregation pheromone of the flour beetles, Tribolium castaneum and T. confusum (Coleoptera: Tenebrionidae). Agric. Biol. Chem. 44, 2519-2520, https://doi.org/10.1080/00021369.1980.10864359 (1980).

37. Aoki, Y. \& Hori, M. Influence of conspecific odor on olfactory behavior of Tribolium confusum. Urban Pest Management 2, 81-89 (2012).

38. Rayanil, K., Bunchornmaspan, P. \& Tuntiwachwuttikul, P. A new phenolic compound with anticancer activity from the wood of Millettia leucantha. Arch. Pharm. Res. 34, 881-886, https://doi.org/10.1007/s12272-011-0603-4 (2011).

39. de Alvarenga, M. A. et al. Dihydroisocoumarins and phthalide from wood samples infested by fungi. Phytochemistry 17, 511-516, https://doi.org/10.1016/S0031-9422(00)89350-4 (1978). 
40. Claydon, N., Frederick, G. \& Pople, M. Elm bark beetle boring and feeding deterrents from Phomopsis oblonga. Phytochemistry 24, 937-943, https://doi.org/10.1016/S0031-9422(00)83157-X (1985).

41. Oluwaseum, A. D. et al. Mellein, a dihydroisocoumarin with bioherbicidal activity from a new strain of Lasiodiplodia pseudotheobromae C1136. BJBAS 7, 505-510, https://doi.org/10.1016/j.bjbas.2018.06.001 (2018).

42. Moore, J. H., Davis, N. D. \& Diener, U. L. Mellein and 4-hydroxymellein production by Aspergillus ochraceus Wilhelm. Appl. Microbiol. 23, 1067-1072 (1972).

43. Samson, R. A., Hong, S.-B. \& Frisvad, J. C. Old and new concept of species differentiation in. Aspergillus. Med. Mycol. 44, S133-S148, https://doi.org/10.1080/13693780600913224 (2006).

44. Cary, J. W., Gilbert, M. K., Lebar, M. D., Majumdar, R. \& Calvo, A. M. Aspergillus flavus secondary metabolites: more than just aflatoxins. Food Safety 6, 7-32, https://doi.org/10.14252/foodsafetyfscj.2017024 (2017).

45. Klich, M. A. Soil fungi of some low-altitude desert cotton fields and ability of their extracts to inhibit Aspergillus flavus. Mycopathologia 142, 97-100, https://doi.org/10.1023/A:1006989712282 (1998).

46. Bayman, P., Baker, J. L., Doster, M. A., Michailides, T. J. \& Mahoney, N. E. Ochratoxin production by the Aspergillus ochraceus group and Aspergillus alliaceus. Appl. Environ. Microb. 68, 2326-2329, https://doi.org/10.1128/AEM.68.5.2326-2329.2002 (2002).

47. Pardo, E., Malín, S., Sanchis, V. \& Ramos, A. J. Prediction of fungal growth and ochratoxin A production by Aspergillus ochraceus on irradiated barley grain as influenced by temperature and water activity. Int. J. Food. Microbiol. 95, 79-88, https://doi.org/10.1016/j. ijfoodmicro.2004.02.003 (2004)

48. Yu, J. \& Ehrlich, K. Aflatoxin biosynthetic pathway and pathway genes in Aflatoxins - biochemistry and molecular biology (ed. Guevara-Gonzalez, R. G.), https://doi.org/10.5772/23034 (Intech Open, 2011).

49. Abdel-Azeem, A. M., Benjamin, W. H., Richards, J. E., Davis, S. L. \& Blanchette, R. A. Assessment of biodegradation in ancient archaeological wood from the middle cemetery at Abydos, Egypt. PLoS One 14, e0213753, https://doi.org/10.1371/journal. pone.0213753 (2019).

50. Dickens, J. C. Olfactory perception of pheromone and host-odour enantiomers by Ips typographus (Coleoptera: Scolytidae). Entomol. Exp. Appl. 24, 136-142, https://doi.org/10.1111/j.1570-7458.1978.tb02790.x (1978).

51. Hobson, K. R. et al. Chiral specificity in responses by the bark beetle Dendroctonus valens to host kairomones. J. Chem. Ecol. 19, 1837-1846, https://doi.org/10.1007/BF00983790 (1993).

52. Bichão, H., Borg-Karlson, A.-K., Wibe, A., Araújo, J. \& Mustaparta, H. Molecular receptive ranges of olfactory receptor neurones responding selectively to terpenoids, aliphatic green leaf volatiles and aromatic compounds, in the strawberry blossom weevil Anthonomus rubi. Chemoecology 15, 211-226, https://doi.org/10.1007/s00049-005-0315-7 (2005).

53. Ulland, S., Ian, E., Borg-Karlson, A.-K. \& Mustaparta, H. Discrimination between enantiomers of linalool by olfactory receptor neurons in the cabbage moth Mamestra brassicae (L.). Chem. Senses 31, 325-334, https://doi.org/10.1093/chemse/bjj036 (2006).

54. Bohbot, J. D. \& Dickens, J. C. Characterization of an enantioselective odorant receptor on the yellow fever mosquito Aedes aegypti. PLoS One 4, e7032, https://doi.org/10.1371/journal.pone.0007032 (2009).

55. Raguso, R. A. More lessons from linalool: insights gained from a ubiquitous floral volatile. Curr. Opin. Plant Biol. 32, 31-36, https:// doi.org/10.1016/j.pbi.2016.05.007 (2016).

\section{Author Contributions}

M.H. designed the experiments, performed the experiments, analysed the data, and wrote the manuscript. Y.A. performed the experiments and analysed the data. K.S. designed the experiments, performed the experiments, and analysed the data. M.C. performed the experiments and analysed the data. R.S. performed the experiments and analysed the data.

\section{Additional Information}

Supplementary information accompanies this paper at https://doi.org/10.1038/s41598-019-48073-9.

Competing Interests: The authors declare no competing interests.

Publisher's note: Springer Nature remains neutral with regard to jurisdictional claims in published maps and institutional affiliations.

(c) (i) Open Access This article is licensed under a Creative Commons Attribution 4.0 International License, which permits use, sharing, adaptation, distribution and reproduction in any medium or format, as long as you give appropriate credit to the original author(s) and the source, provide a link to the Creative Commons license, and indicate if changes were made. The images or other third party material in this article are included in the article's Creative Commons license, unless indicated otherwise in a credit line to the material. If material is not included in the article's Creative Commons license and your intended use is not permitted by statutory regulation or exceeds the permitted use, you will need to obtain permission directly from the copyright holder. To view a copy of this license, visit http://creativecommons.org/licenses/by/4.0/.

(C) The Author(s) 2019 